\title{
Langerhans cell density and serological changes following intradermal immunisation of mice with dengue 2 virus
}

\author{
SUWIMOL TAWEECHAISUPAPONG, SIRIPORN SRIURAIRATANA*, SUBHKIJ ANGSUBHAKORN, \\ SUTEE YOKSAN†, MI MI KHIN $\dagger$, SOMPHONG SAHAPHONG and NATTH BHAMARAPRAVATI $\dagger$ \\ Department of Pathobiology, Faculty of Science, Mahidol University, Rama 6 Road, *Department of Pathology, \\ Faculty of Medicine, Ramathibodi Hospital, Rama 6 Road, Bangkok 10400 and †Center for Vaccine \\ Development, Institute of Science and Technology for Development, Mahidol University at Salaya, Nakhon \\ Pathom 73170, Thailand
}

\begin{abstract}
After the introduction of the dengue-2 (16681) virus by intradermal (i.d.) injection into the footpads of mice, Langerhans cells (LCs) increased in numbers within $24 \mathrm{~h}$ at the site of injection and neutralising antibody developed. On comparing the i.d. and intramuscular (i.m.) routes, antibody was produced more rapidly and at higher levels when the virus was injected by the i.d. route. Subsequent re-challenge by the i.d. route produced an even more rapid serological response with all mice producing significant neutralising titres within $12 \mathrm{~h}$. Numbers of ATPase-positive LCs varied with time. A significant sharp drop in LC densities in the early post-injection phase directly correlated with the increased numbers of dendritic cells in the superficial dermis and interfollicular sinuses of draining lymph nodes (LN). Immunofluorescence showed the presence of viral antigen in the footpad epidermis and draining $\mathrm{LN}$ within minutes or within $2 \mathrm{~h}$ of challenge, respectively.
\end{abstract}

\section{Introduction}

Intradermal (i.d.) vaccination has received increasing interest as it requires only a small dose of antigen and induces good antibody titres. Various strategies for reducing the volume of vaccine injected without diminution in immune responses have been considered for vaccines that are expensive or scarce. These studies have shown economic success rates of $60-90 \%$. Vaccines currently administered successfully by the i.d. route are bacterial vaccines such as diphtheria/ tetanus/pertussis (DPT) [1], cholera [2], BCG [3], and viral vaccines such as influenza [4], rabies [5,6] and more recently hepatitis B [7]. Furthermore, i.d. injections by painless jet injector, which demands less skill, appear to provide a successful method for mass vaccination programmes [1].

The local cellular basis responsible for induction of systemic immunity after i.d. injection has not yet been studied. However, epidermal Langerhans cells (LCs) are known to play a critical role as antigen-presenting cells [8]. Different types of antigens (simple haptens,

Received 1 May 1995; revised version accepted 22 Dec. 1995. Corresponding author: Professor S. Angsubhakorn. metals, proteins or viruses) have been shown to be taken up or presented to T-helper cells, or both, by the LCs [9-11]. Futhermore, LCs were found to play an important role in the control of vaccinia virus infection in human skin [12] and in defence against i.d. injected HSV-1 in mice [13]. Dengue virus, which causes dengue haemorrhagic fever (DHF) and dengue shock syndrome (DSS) [14], poses a considerable health problem in many areas of the world; i.e. Southeast Asia, Central and South America, the Caribbean and Africa. Thus, the development of a safe, effective, inexpensive and readily available vaccine is a crucial step in control of dengue infection. In pursuit of an effective route of administration of the live attenuated vaccine, the cutaneous cellular involvement and the immune response after primary and secondary i.d. injection with dengue-2 (DEN-2) virus in mice were investigated.

\section{Materials and methods}

Mice

A total of 230 male inbred BALB/c mice obtained from the Center for Vaccine Development, Mahidol University at Salaya, Thailand, was used. All mice were 8 weeks old, kept four-to-six/cage, and provided with standard mouse pellets (KMP Feedmills PTE LTD, Jurong, Singapore) and water ad libitum. 


\section{Virus strain}

DEN-2 virus (16681), titre $2.7 \times 10^{5} \mathrm{pfu} / \mathrm{ml}$, isolated from the serum of a DHF patient with DHF in Bangkok, Thailand [15], was obtained from the Center for Vaccine Development, Mahidol University. This strain is the parent strain of the DEN-2 PDK 53 candidate vaccine virus.

\section{Mouse challenge}

Preliminary experiments established that a volume of $0.05 \mathrm{ml}$ of virus inoculum was tolerable for the footpad skin, when injected i.d. with a 25 -gauge needle. An inoculum of $0.05 \mathrm{ml}$ was therefore used throughout. Only mice receiving a successful i.d. injection, demonstrated by the characteristic blister, were included in the experimental groups.

Primary antibody response. Two groups of 40 mice were anaesthetised with Nembutal (Sanofi Animals s.a. Paris, France). For mice in group 1, $0.05 \mathrm{ml}$ of DEN-2 virus $\left(1.35 \times 10^{4} \mathrm{pfu}\right)$ was injected i.d. into the right hind footpad (RFP). For 20 mice from group 2, the same dose was injected i.d. into the RFP and for the other 20 , the same dose was injected i.m. into the right thigh.

Secondary antibody response. Mice were divided into two groups. Mice in both groups were anaesthetised with Nembutal and $0.05 \mathrm{ml}$ of DEN-2 virus $\left(1.35 \times 10^{4} \mathrm{pfu}\right)$ was injected i.d. into their RFP. At day 35 after the first injection, mice in group 1 were again received by the same dose of virus $\left(1.35 \times 10^{4} \mathrm{pfu}\right)$ i.d. injection into the RFP. For group 2 mice the second dose was injected into the LFP.

\section{Enzyme histochemistry of epidermal LCs}

Specimens of skin were excised from the hind footpads at the same time as the blood was collected for serology. The skin was incubated at $37^{\circ} \mathrm{C}$ in a buffered solution of $20 \mathrm{mM}$ EDTA ( $\mathrm{pH} \mathrm{7.4)}$ ) for $2 \mathrm{~h}$ as described by Scaletta and MacCallum [17]. Whole epithelial sheets were readily separated from the dermis with watchmaker's forceps. The epidermal sheets obtained were fixed and incubated to demonstrate ATPase activity as described previously [18]. LCs in the epidermal sheet were then visualised by light microscopy and their numbers were estimated with an eyepiece graticule. Twenty fields chosen at random for each specimen were counted. The area of the field count was calculated and LC density was expressed per $\mathrm{mm}^{2}$ of epidermal surface area.

\section{Size measurement and histological study of popliteal lymph nodes}

Popliteal lymph nodes (LN) were removed from both sides at the same time intervals as the footpad skin and measured with a vernier caliper (Mitutoyo, Japan); the size of the LNs was expressed in $\mathrm{mm}^{3}$. They were then fixed in phosphate-buffered formalin $10 \%$, stained with haematoxylin and eosin, and examined by light microscopy.

\section{Neutralisation test}

Serum samples collected before injection and on days $1,7,14,21,28,35$ and 42 after injection were examined for plaque reduction neutralising antibodies (PRNT) as described previously [16].

\section{Histological study of footpad skin}

At 2, 5, 10 and $15 \mathrm{~min}$ and $2 \mathrm{~h}$ after a single i.d. injection into the RFP, footpad skin was excised from both sides and fixed overnight in glutaraldehyde $1 \%$ plus paraformaldehyde $4 \%$ in $0.1 \mathrm{M}$ phosphate buffer. They were post-fixed in osmium tetroxide $1 \%$ in $0.1 \mathrm{M}$ phosphate buffer for $2 \mathrm{~h}$, dehydrated through a graded series of alcohol and embedded in EM bed 812 (Electron Microscopy Science, Washington, PA, USA). Sections $(1 \mu)$ were cut and stained with toluidine blue [20] for light microscopy.

\section{Immunofluorescence}

At 2, 5, 10 and $15 \mathrm{~min}$ and $2 \mathrm{~h}$ after a single i.d. injection into the RFP, footpad skin and popliteal LNs were excised from both sides and snap frozen. Cryostat sections of $6 \mu \mathrm{m}$ thickness were picked up on slides, stained with FITC-conjugated anti-dengue antibody [19] and mounted in buffered glycerol.

\section{Statistical analysis}

For statistical comparison between LC densities in RFP and LFP, the unpaired two-tailed Student's $t$-test was used and a p-value of $<0.05$ was regarded as significant.

\section{Results}

The blister formed on the footpads after injection generally subsided within $2 \mathrm{~h}$ and completely disappeared by the next day.

\section{$L C$ densities and antibody response after the first injection}

Epidermal LC densities in RFP and LFP are shown in Fig. 1a. The LC densities in the RFP increased slightly at the site of injection by day 1 , dropped significantly $(p<0.01)$ on day 7 and were lowest by day 14. The LCs then gradually increased in numbers and by day 35 had returned to the same density as on day 0 . Similarly, in the LFP, the LC densities dropped significantly $(p<0.01)$ by day 7 , as for the RFP, and were lowest by 

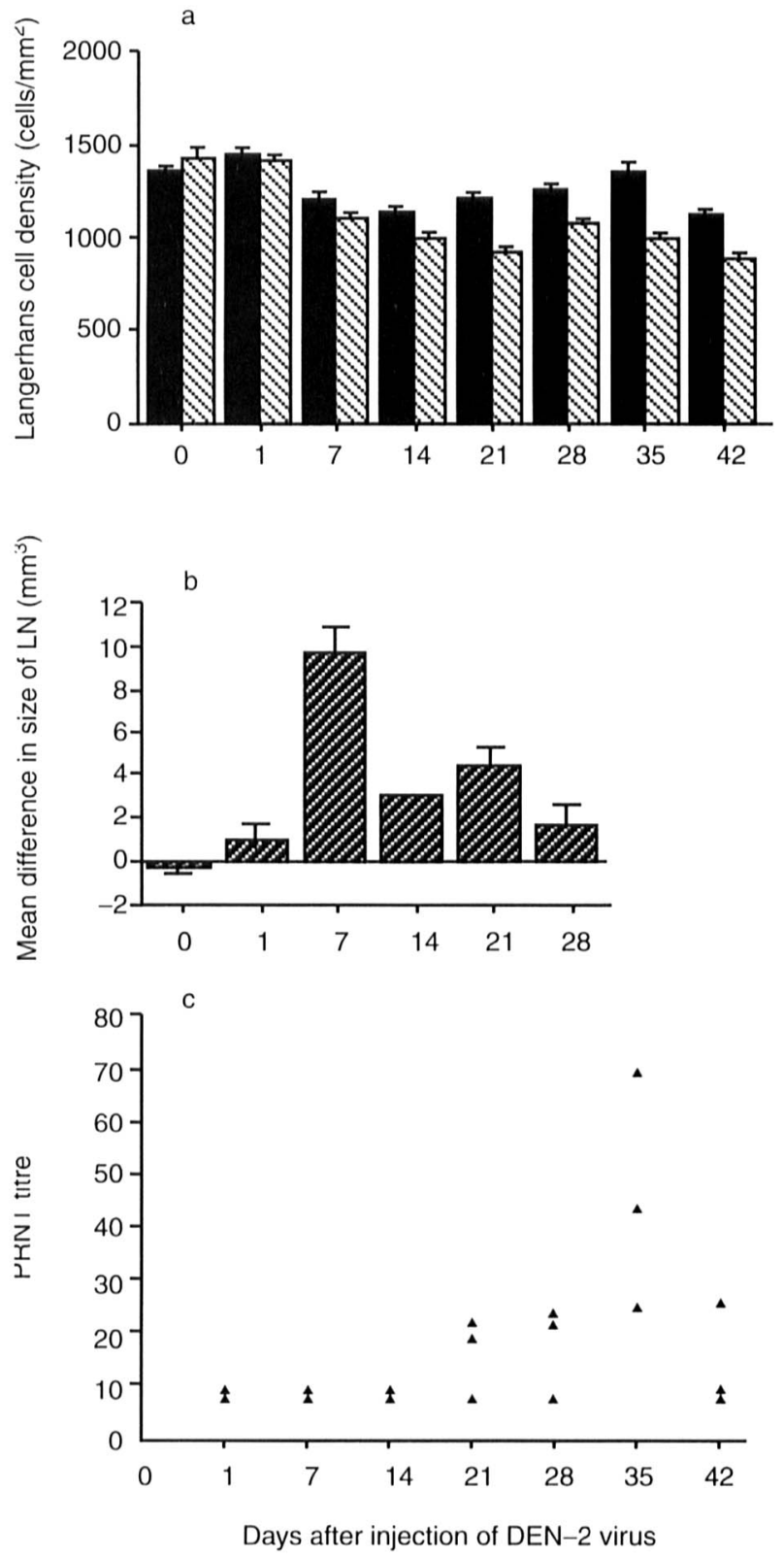

Fig. 1. (a) Epidermal LC densities in right ( $\square$ ) and left $(\mathbb{E})$ hind footpads of mice, after primary i.d. injection of DEN-2 virus into the RFP. The densities were determined by staining the epidermal sheets of 3-4 mice/time interval for ATPase activity. Results are expressed as cells $/ \mathrm{mm}^{2}$ and SEM. (b) Mean difference in size $\left(\mathrm{mm}^{3}\right)$ of 6-8 right minus left popliteal $\mathrm{LN}$ from the mice as in (a). (c) The serum PRNT titres of the same mice as in (a) and (b).

day 21. On day 28 , the LC densities in LFP had recovered, but only to the same density as on day 7 .

The mean differences in size of the popliteal $\mathrm{LN}$ on the right minus the left in relation to the period after injection are shown in Fig. $1 \mathrm{~b}$. The right popliteal $\mathrm{LN}$ showed two phases of enlargement on days 7 and 21 . Microscopy of the enlarged LN showed hypercellularity of the paracortical area, including loss of demarcation between cortical and paracortical zones. There was a marked increase in the number of tingible body macrophages on day 1 and day 7. Few germinal centres were detected on day 14 .

Serum PRNT titres to DEN-2 virus in the mice group 1 after a single i.d. injection were first detected on day 21 in two of three mice (titres 19 and 22), and they gradually increased until day 35 . The antibody titres had declined by day 42 (Fig. 1c). In the mice in group 2, which were matched for comparison of the immune response between mice receiving i.d. versus i.m. injections, it was demonstrated clearly that higher PRNT titres developed in mice that received i.d. injection and these responses were seen from day 7 to day 28 (Table 1).

\section{Histological findings in Epon sections}

Semi-thin Epon sections of normal footpad skin showed moderate numbers of clear cytoplasmic cells residing between the keratinocytes in the basal zone (Fig. 2A and B). Occasionally, dendritic cells (DC) were present in the uppermost dermis, beneath the epidermal basement membrane (hereafter called superficial dermis). In the footpad skin into which virus had been injected, marked changes were first observed $5 \mathrm{~min}$ after injection. There were increased numbers of LCs in the epidermis and stellate shaped DC in the superficial dermis. Numerous LCs were seen around the area of viral inoculum deposit after $15 \mathrm{~min}$ (Fig. 2C-E). An acute inflammatory reaction was not found, but mast cell degranulation could be noted in the microvascular zone. A mild degree of hyperamia was sometimes observed in some of the capillaries. No other histological abnormalities were seen.

After $2 \mathrm{~h}$, the area of inoculum deposit in the epidermis had disappeared. The number of LCs in the epidermis had decreased and the numbers of DC in superficial dermis were markedly increased. In the popliteal $\mathrm{LN}$, an increase in the number of DC was seen in the interfollicular sinuses; they were surrounded by numerous lymphocytes.

\section{Immunofluorescence}

At 2 and 5 min after injection, the footpad skin showed clumps and small specks of antigen reacting with

Table 1. Plaque-reduction neutralising antibody (PRNT) titres attained after intradermal (i.d.) and intramuscular (i.m.) injection of DEN-2 virus

\begin{tabular}{lcc}
\hline $\begin{array}{l}\text { Days } \\
\text { after }\end{array}$ & \multicolumn{2}{c}{ PRNT titres after injection* } \\
\cline { 2 - 3 } injection & i.d. & i.m. \\
\hline 7 & $<10,<10,13,13,14$ & $<10,<10,<10,<10,<10$ \\
14 & $<10,<10,<10,11,100$ & $<10,<10,<10,12,27$ \\
21 & $14,25,26,27,27$ & $<10,<10,25,25,29$ \\
28 & $<10,22,24,50,180$ & $<10,<10,<10,<10,14$ \\
\hline
\end{tabular}

${ }^{*}$ Mice were given $0.05 \mathrm{ml}$ of DEN-2 virus $\left(1.35 \times 10^{4} \mathrm{pfu}\right)$ i.d. into their RFP or i.m. into their right thigh. Each group consisted of five mice. 

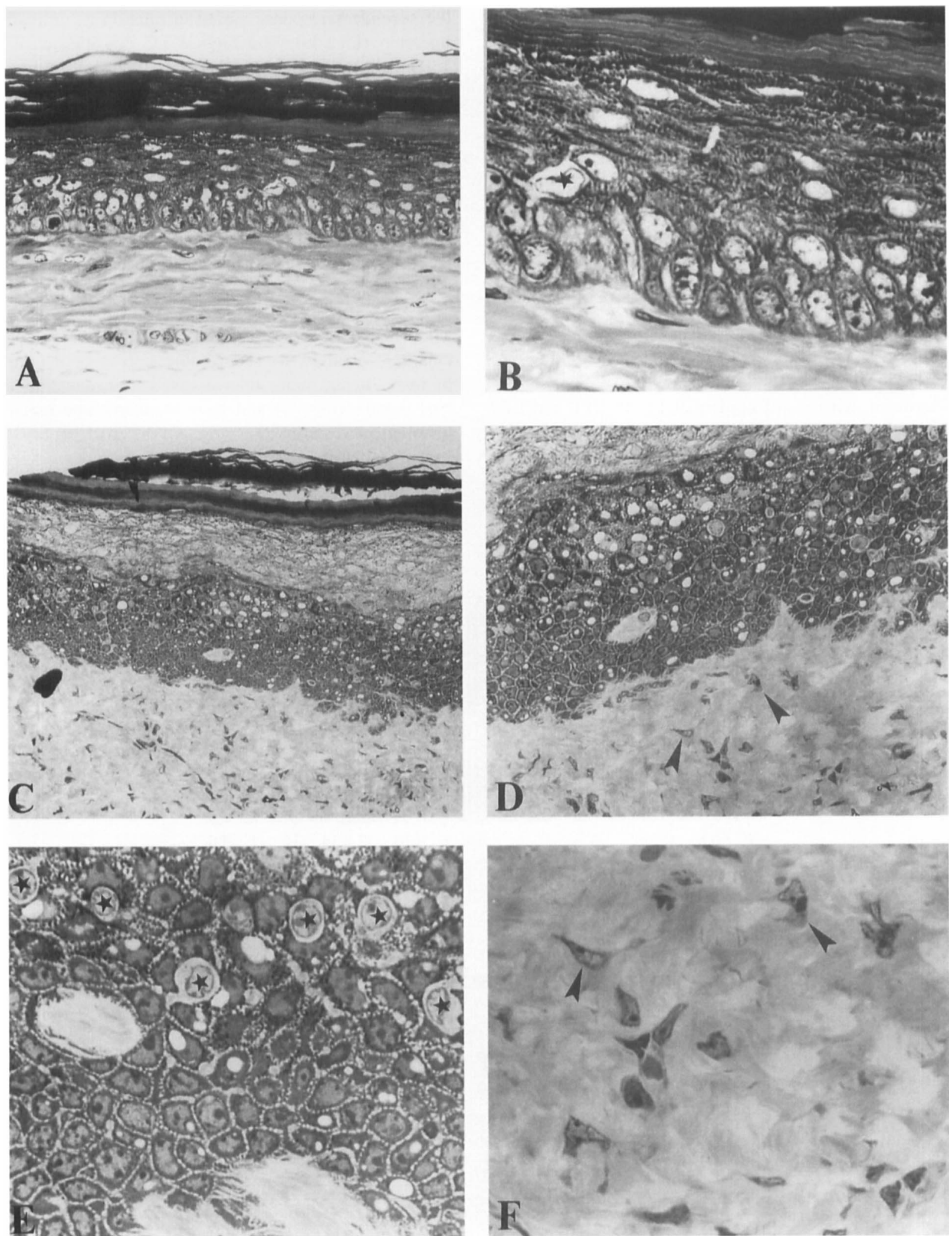

Fig. 2. Photomicrographs of toluidine blue-stained Epon sections of normal footpad skin and footpad skin into which DEN-2 virus had been injected i.d. $15 \mathrm{~min}$ before sampling. (A) Normal RFP skin showing the epidermis and upper dermis $(\times 400)$. (B) High magnification of (A) showing a LC $(\star)$ in the epidermis $(\times 1000)$. (C) Low magnification view of a footpad blister, sectioned in a plane oblique to the vertical, showing a lightly stained zone consisting of the stratum granulosum and the upper stratum spinosum. Note the numerous DC in the dermis $(\times 200)$. (D) Higher magnification of the central part in $(C)$, showing numerous LC among the keratinocytes close to the lightly stained zone, and dermal DC $\longrightarrow(\times 400)$. (E) High magnification of epidermis in the left part of (c), showing the LC ( $\star$ ) and their dendritic processes $(\times 1000)$. (F) High magnification of DC in the lower part of (D), showing their stellate morphology $\longrightarrow(\times 1000)$. 
FITC-conjugated anti-dengue antibody in scattered foci within both the epidermis and superficial dermis. However, it was not clear whether they were inside or outside cells. The control tissue that had not received an injection of virus did not show any fluorescence. After 10 and $15 \mathrm{~min}$ and $2 \mathrm{~h}$, the clumps of antigen had diminished, and an increase in specks of antigen was observed. The ipsilateral draining LN collected at $2 \mathrm{~h}$ after injection showed a few scattered single cells reacting with the FITC-conjugated antidengue antibody in the cortical zone. The fluorescence was diffuse around the periphery of the cells.

\section{LC densities and serological response after second injection}

The mean densities of epidermal LC in RFP and LFP in mice in groups 1 and 2 in the experiment to examine the secondary response varied in relation to time after injection (Fig. 3a). The highest LC densities were $c$. 1500 cells $/ \mathrm{mm}^{2}$ and the lowest $c .900$ cells $/ \mathrm{mm}^{2}$. A statistically significant $(\mathrm{p}<0.01)$ alternating high rise and sharp drop in LC densities were noted on day 1 through to day 4 in both RFP and LFP in mice in group 1 that were given the second dose into the RFP. In group 2 mice that were given the second dose into the LFP, a sharp drop in LC densities in both footpads was noted on days 2 and 3 followed by a high rise on day 4 , which fluctuated insignificantly through to day 56 .

The ipsilateral draining LN showed a gradual enlargement after the second injection in both groups of mice. It had more than doubled in size within the first 3 days (Fig. 3b) and there were immune reactive histological features.
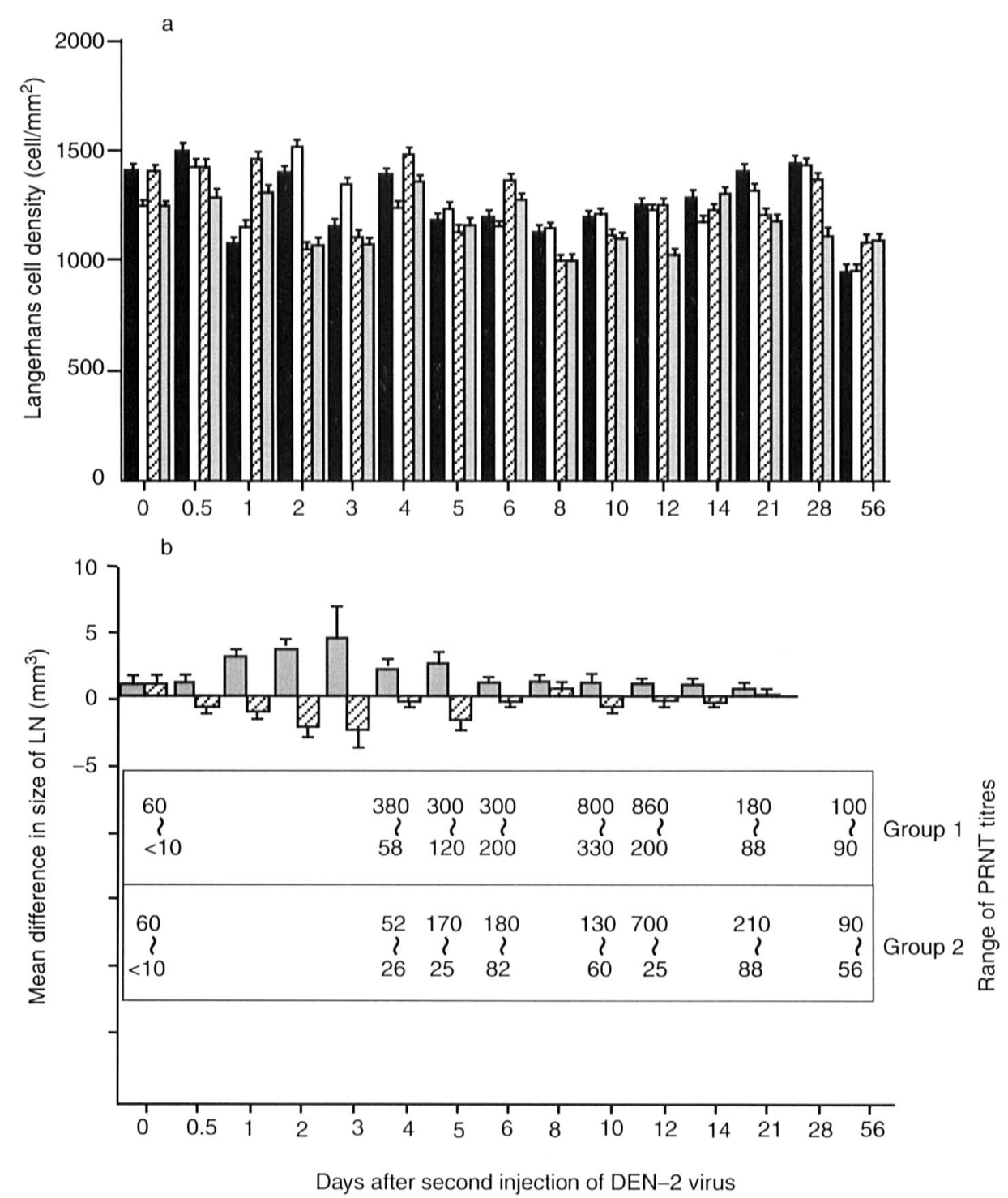

Fig. 3. (a) Epidermal LC densities in both hind footpads of mice after the second i.d. injection of DEN-2 virus into the RFP of mice in group 1 and the LFP of mice in group 2: $\mathbf{0}$, RFP group 1; $\square$, LFP group 1; , RFP group 2; : LFP group 2. The densities were determined by staining the epidermal sheets of 3-10 mice/time interval for ATPase activity. Results are expressed as cells $/ \mathrm{mm}^{2}$ and SEM. (b) Mean difference in size $\left(\mathrm{mm}^{3}\right)$ of $6-20$ right minus left popliteal LN from mice as in (a) and range of serum PRNT titres. 
The earlier rise in PRNT titres as detected 4 days after the second injection in both groups of mice (Fig. 2b, Table 2). Markedly higher titres were noted in group 1 mice, commencing on day 4 and reaching a plateau within 12 days after injection. The maximum titres attained were $>14$ times higher than the primary PRNT titres. By day 21, both groups of mice showed declining titres of neutralising antibodies, nevertheless, high titres of antibodies persisted throughout the study period.

\section{Discussion}

The present study showed evidence that i.d. immunisation of mice with DEN-2 virus initiated both the primary and secondary immune responses (Table 1 and Table 2). In the matched groups of mice, the i.d. route induced a greater primary immune response in most of the experimental mice than did i.m. injection. The lag phase before antibody production was shorter and PRNT titres were higher and persisted longer after i.d. injection. The secondary antibody response was more intense when the second injection was given in the same footpad as the first. Extrapolating from the intense reactive response observed here, it is possible that a small dose of virus in the second booster injection would be adequate and appropriate to produce solid protective immunity.

Epidermal LC densities at various time intervals after i.d. injection varied (Figs. 1a, 2a). One possible explanation for the change is that the migratory activities of epidermal LCs varied after exposure to the virus. It is well established that LC have the ability to pass through the basement membrane into the dermis [21, 22], where they are re-named dendritic cells (DC). In the present study, an increased number of DC was first observed in the dermis of the footpad

Table 2. Plaque-reduction neutralising antibody (PRNT) titres attained after a second i.d. injection of DEN-2 virus

\begin{tabular}{lcc}
\hline \multirow{2}{*}{$\begin{array}{l}\text { Days } \\
\text { after } \\
\text { second }\end{array}$} & \multicolumn{2}{c}{ PRNT titre } \\
\cline { 2 - 3 } injection & Group $1^{*}$ & Group 2 \\
\hline 0 & $<10,<10,<10,<10,<10,12,22,22,44,60$ \\
0.5 & $23,46,56,60$ & $22,23,29$ \\
1 & $24,24,24,25,25$ & $12,12,19,20,26$ \\
2 & $42,42,42,50,84$ & $50,64,84$ \\
4 & $58,58,94,150,170,380$ & $26,26,26,49,52,52$ \\
5 & $120,170,190,210,300$ & $25,92,100,120,170$ \\
6 & $200,210,230,260,270,300$ & $82,94,120,120,180$ \\
10 & $330,370,380,380,800$ & $60,86,92,130$ \\
12 & $200,740,800,800,820,860$ & $25,94,140,190,200,700$ \\
21 & $88,90,96,100,180$ & $88,90,98,98,210$ \\
28 & $86,88,100$ & 50,92 \\
56 & 90,100 & $56,84,90$ \\
\hline
\end{tabular}

${ }^{*}$ Mice were first given $0.05 \mathrm{ml}$ of DEN-2 virus $\left(1.35 \times 10^{4} \mathrm{pfu}\right)$ by i.d. injection into their RFP followed by a second injection into the same (group 1) or the other (group 2) footpad 35 days after the first injection. Each group consisted of 3-10 mice. skin 5 min after injection. Most of the DC were in the superficial dermis. The immunophysiology of LC migration is not clear at present. However, there is evidence from this study of LC migration from the epidermis after virus injection, as increased numbers of DC in the dermis correlated with the reduction of the local density of epidermal LCs at the site of antigenic challenge. After this phase, it was noteworthy that the LC density at the site of antigenic challenge increased. A probable explanation for this may be that LCs in the surrounding epidermis and more remote areas were attracted to the antigen challenge site to replenish LC number and to facilitate transport of the antigen to the draining LN. Another explanation that could be considered for the increase in LCs is that there is a continuous supply of LCs from the blood bringing precursors originating in the bone marrow [23]. Many experiments have indicated that the mechanisms underlying LC movement are mediator dependent [24-26]. The present study did not demonstrate the presence of mediators, although migration of LCs was apparent. Based on these data, we propose that the increase and decrease in LC densities observed in present experiments reflects a state in which the rate of LC replenishment at the site of antigenic challenge in the footpad is higher or lower than the rate of migration. As the statistically significant $(p<0.01)$ slight increases and sharp decreases in LC densities occurred in the early phase after injection, it is probable that a large number of LCs had migrated rapidly out of the epidermis at a rate far exceeding that of replenishment. The finding that decreased LC densities in the LFP (that had not received an injection of virus) paralleled those in the RFP (into which virus had been injected) between days 7 and 21 of the experiment (Fig. 1a) was unexpected. However, it is possible that an intradermal mobilisation of remote epidermal LCs was underway to reinforce the depleted LCs surrounding the antigen challenge site. Similarly, a parallel variation in LC densities was apparent in the experiment conducted to demonstrate the effects after the second injection (Fig. 2a). Among the varying densities of LCs, the highest observed were 1505 SEM 31 and 1493 SEM 26 cells/ $\mathrm{mm}^{2}$, in mice of groups 1 and 2 , respectively, and were slightly elevated from the normal, 1441 SEM 37 cells $/ \mathrm{mm}^{2}$. The lowest densities of LCs were 973 SEM 36 and $1056 \mathrm{SEM} 24$ cells $/ \mathrm{mm}^{2}$ in mice of groups 1 and 2 , respectively. The decrease was approximately one-third of the normal density. A similar observation of reduction by one-third has also been observed by other investigators [27-29], after application of contact allergens followed by immunolabelling of an epidermal sheet preparation. This one-third decrease may represent the migration capacity or physiological limit of epidermal LC density.

Massive migration of LCs in the early phase after the first or second injection of $\mathrm{DEN}-2$ virus led to an accumulation of DC in popliteal LN which was 
evident from the histological sections. Immunofluorescent staining confirmed the deposition of inoculated antigen in the cutaneous areas a few minutes after injection. Further antigen-bearing cells could be localised in the draining $\mathrm{LN}$ by $2 \mathrm{~h}$. This observation is consistent with those of several other investigators $[30,31]$ who examined skin sensitisation of mice. Furthermore, Kripke et al. [32] have provided compelling evidence that the antigen-bearing lymph node DC are derived from epidermal LCs. Neefjes and Ploegh [33] have recently shown that, after endocytosis of exogenous antigen, antigen-presenting cells degrade the antigen in the endocytic pathway and fragments of this antigen are associated with $\mathrm{MHC}$ class II molecules. The peptide-class II complex takes 1-3 $\mathrm{h}$ to transverse the endocytic route and re-appear at the cell surface. The observations in the present study of dengue antigen-bearing cells in the draining LN $2 \mathrm{~h}$ after injection are in accordance with the time required for intracellular assembly and transport of MHC class II molecules to complex with the processed antigen, which is then expressed on the cell surface for recognition by $\mathrm{T}$-helper cells.

Enlargement of the ipsilateral popliteal LN during the development of both primary and secondary serological responses (Figs. 1b, 3b) is consistent with observations in immune reactive $\mathrm{LN}$ by several investigators $[34,35]$. The first enlargement of $\mathrm{LN}$ is due to the accumulation of DC, increasing lymphocyte influx, inhibition of lymphocyte exit and oedema $[36,37]$. At the end of lymphocyte recruitment, the size of LN decreased for a variable period of time and was followed by a second enlargement phase. This was related to continued increase in the proliferation of germinal centres and increased LN cellularity. These experiments have shown also that rising levels of antibodies correlated with the day of secondary enlargement of $\mathrm{LN}$ both after the first and second virus injection (Figs. 1b, 1c, 3b). The possibility of an alternative antigen pathway [38] which operated in the secondary immune response in the mice was not investigated in this study.

The cellular events observed in the present study showed that it was solely the skin LC/DC that exercised the role of antigen transport and presentation that stimulates an adequate co-operation between the effector phases of the immune system to elicit the success of i.d. immunisation. The skin LC play a crucial role as potent antigen-presenting cells when compared with others in the macrophage-monocyte lineage.

We are grateful to Professor Y. Becker for technical advice in ATPase staining and for kindly providing some materials, and to $T$ Subsomboon, S. Thongwan, A. Pradermwong, S. Amapana, V. Duangjinda and B. Thanomrod for technical assistance. This work was supported in part by the Dengue Vaccine Development project (Natth Bhamarapravati, Principal Investigator) of the Center for Vaccine Development of Mahidol University.

\section{References}

1. Stanfield JP, Bracken PM, Waddell KM, Gall D. Diphtheriatetanus-pertussis immunization by intradermal jet injection. BMJ 1972; 2: 197-199.

2. Anonymous. A controlled field trial on the effectiveness of the intradermal and subcutaneous administration of cholera vaccine in the Philippines. Bull World Health Organ 1973; 49: 389394.

3. Anonymous. A comparison of intradermal BCG vaccination by jet injection and by syringe and needle. Tubercle 1971; 52: 155 -165 .

4. Payler DK, Skirrow MB. Intradermal influenza vaccination. BMJ 1974; 2: 727.

5. Ubol S, Phanuphak P. An effective economical intradermal regimen of human diploid cell rabies vaccination for postexposure treatment. Clin Exp Immunol 1986; 63: 491-497.

6. Briggs DJ, Schwenke JR. Longevity of rabies antibody titres in recipients of human diploid cell rabies vaccine. Vaccine 1992; 10: $125-129$.

7. Bryan JP, Sjogren MH, Perine PL, Legters LJ. Low-dose intradermal and intramuscular vaccination against hepatitis $B$. Clin Infect Dis 1992; 14: 697-707.

8. Katz SI, Cooper KD, lijima M, Tsuchida T. The role of Langerhans cells in antigen presentation. $J$ Invest Dermatol 1985; 85(1 Suppl): 96s-98s.

9. Braathen LR, Thorsby E. Studies on human epidermal Langerhans cells. I. Allo-activating and antigen-presenting capacity. Scand J Immunol 1980; 11: 401-408.

10. Hayashi $Y$, Aurelian L. Immunity to herpes simplex virus type 2: viral antigen-presenting capacity of epidermal cells and its impairment by ultraviolet irradiation. J Immunol 1986; 136: 1087-1092.

11. Shelley WB, Juhlin L. Langerhans cells form a reticuloepithelial trap for external contact antigens. Nature 1976; 261: 46-47.

12. Nagao S, Inaba S, Iijima S. Langerhans cells at the sites of vaccinia virus inoculation. Arch Dermatol Res 1976; 256: $23-$ 31 .

13. Sprecher E, Becker Y. Langerhans cell density and activity in mouse skin and lymph nodes affect herpes simplex type 1 (HSV-1) pathogenicity. Arch Virol 1989; 107: 191-205.

14. Halstead SB. Pathogenesis of dengue: challenges to molecular biology. Science 1988; 239: 476-481.

15. Halstead SB, Udomsakdi S, Simasthien P, Singharaj P, Sukhavachana P, Nisalak A. Observations related to pathogenesis of dengue hemorrhagic fever. I. Experience with classification of dengue viruses. Yale J Biol Med 1970; 42: 261-275.

16. Russell PK, Nisalak A, Sukhavachana P, Vivona S. A plaque reduction test for dengue virus neutralizing antibodies. J Immunol 1967; 99: 285-290.

17. Scaletta LJ, MacCallum DK. A fine structural study of divalent cation-mediated epithelial union with connective tissue in human oral mucosa. Am J Anat 1972; 133: 431-453.

18. Mackenzie IC, Squier CA. Cytochemical identification of ATPase-positive Langerhans cells in EDTA-separated sheets of mouse epidermis. Br J Dermatol 1975; 92: 523-533.

19. Kuberski TT, Rosen L. A simple technique for the detection of dengue antigen in mosquitoes by immunofluorescence. $\mathrm{Am} \mathrm{J}$ Trop Med Hyg 1977; 26: 533-537.

20. Trump BF, Smuckler EA, Benditt EP. A method for staining epoxy sections for light microscopy. J Ultrastruct Res 1961; 5: 343-348.

21. Larsen CP, Steinman RM, Witmer-Pack M, Hankins DF, Morris PJ, Austyn JM. Migration and maturation of Langerhans cells in skin transplants and explants. J Exp Med 1990; 172: $1483-1493$.

22. Silberberg-Sinakin I, Thorbecke GJ, Baer RL, Rosenthal SA, Berezowsky V. Antigen-bearing Langerhans cells in skin, dermal lymphatics and in lymph nodes. Cell Immunol 1976; 25: $137-151$

23. Katz SI, Tamaki K, Sachs DH. Epidermal Langerhans cells are derived from cells originating in bone marrow. Nature 1979 ; 282: $324-326$.

24. Ioffreda MD, Whitaker D, Murphy GF. Mast cells degranulation upregulates alpha 6 integrins on epidermal Langerhans cells. $\quad J$ Invest Dermatol 1993; 101: 150-154.

25. Kimber I, Cumberbatch M. Stimulation of Langerhans cell 
migration by tumor necrosis factor alpha (TNF-alpha). $J$ Invest Dermatol 1992; 99 Suppl: 48s-50s.

26. Staquet M-J, Levarlet B, Dezutter-Dambuyant C, Schmitt D. Human epidermal Langerhans cells express beta 1 integrins that mediate their adhesion to laminin and fibronectin. $J$ Invest Dermatol 1992; 99 Suppl: 12s-14s.

27. Bergstresser PR, Toews GB, Streilein JW. Natural and perturbed distributions of Langerhans cells: responses to ultraviolet light, heterotopic skin grafting and dinitrofluorobenzene sensitization. J Invest Dermatol 1980; 75: 73 77

28. Botham PA, Rattray NJ, Walsh ST, Riley EJ. Control of the immune response to contact sensitizing chemicals by cutaneous antigen-presenting cells. Br J Dermatol 1987; 117: 1-9.

29. Weinlich G, Sepp N, Koch F, Schuler G, Romani N. Evidence that Langerhans cells rapidly disappear from the epidermis in response to contact sensitizers but not to tolerogens nonsensitizers. Arch Dermatol Res 1989; 281: 556.

30. Kinnaird A, Peters SW, Foster JR, Kimber I. Dendritic cell accumulation in draining lymph nodes during the induction phase of contact allergy in mice. Int Arch Allergy Appl Immunol 1989; 89: 202-210.

31. Macatonia SE, Knight SC, Edwards AJ, Griffiths S, Fryer P. Localization of antigen on lymph node dendritic cells after exposure to the contact sensitizer fluorescein isothiocyanate Functional and morphological studies. J Exp Med 1987; 166: $1654-1667$.

32. Kripke ML, Munn CG, Jeevan A, Tang J-M, Bucana C. Evidence that cutaneous antigen-presenting cells migrate to regional lymph nodes during contact sensitization. $J$ Immunol 1990; 145: 2833-2838.

33. Neefjes JJ, Ploegh HL. Intracellular transport of MHC class II molecules. Immunol Today 1992; 13: 179-184.

34. Szakal AK, Kosco MH, Tew JG. Microanatomy of lymphoid tissue during humoral immune responses: structure function relationships. Annu Rev Immunol 1989; 7: 91-109.

35. Tew JG, DiLosa RM, Burton GF et al. Germinal centers and antibody production in bone marrow. Immunolo Rev 1992; 126: $99-112$.

36. Cahill RNP, Frost H, Trnka Z. The effects of antigen on the migration of recirculating lymphocytes through single lymph nodes. J Exp Med 1976; 143: 870-888.

37. Hay JB, Johnston MG, Vadas P, Chin W, Issekutz T, Movat HZ. Relationships between changes in blood flow and lymphocyte migration induced by antigen. Monogr Allergy 1980; 16: 112-125.

38. Tew JG, Kosco MH, Szakal AK. The alternative antigen pathway. Immunol Today 1989; 10: 229-232. 